\title{
Seosanski Park Cheomji Nori kao primjer očuvanja nematerijalne kulturne baštine u Republici Koreji na regionalnoj razini
}

- Autor predstavlja rezultate istraživanja provedenoga tijekom petomjesečnoga studijskog boravka u Korejskom nacionalnom etnografskom muzeju 2017. godine u sklopu međunarodnoga programa profesionalne razmjene Inicijativa za kulturno partnerstvo (CPI) Ministarstva kulture, sporta i turizma Republike Koreje, čiji je cilj bio proučiti korejski sustav očuvanja nematerijalne kulturne baštine, kao i njegove efekte na institucionalnoj i komunalnoj razini. Rad problematizira potonje, a fokusira se na prakse očuvanja lokalno specifične lutkarske predstave Park Cheomji Nori koja je uvrštena u Regionalni registar nematerijalne kulturne baštine.

Ključne riječi: nematerijalna kulturna baština, tradicijsko kazalište, Park Cheomji Nori, Republika Koreja

\section{UVOD}

Nedugo nakon povratka sa studijskoga boravka u Republici Koreji objavio sam prilog "Kratak pregled sustava zaštite nematerijalne kulturne baštine u Republici Koreji" (Dronjić 2017: 9-25). Koncipirao sam ga kao prvi u nizu radova na temu iz naslova, u kojem je težište na prikazu povijesnoga konteksta razvoja Sustava očuvanja nematerijalne kulturne baštine, s posebnim osvrtom na njegove ključne elemente: sustav baštinjenja (sustav transfera vještina, znanja i umijeća) i sustav registra (administrativni sustav organiziran na nacionalnoj i regionalnoj razini). Ukratko, uspostava Sustava započela je 
pedesetih godina 20. stoljeća te se razvijao sukladno paradigmi neraskidive povezanosti tradicijske kulture i nacionalnoga identiteta. Zahvaljujući uspostavljenom zakonskom okviru i mreži međusobno vrlo dobro povezanih administrativnih tijela, institucija i raznih organizacija, Sustav se pokazao vrlo učinkovitim, ali su se njegovom primjenom pojavili određen izazovi (Dronjić 2017: 21-22, Kim et al. 2012: 95, Yim 2004: 11).

Cilj je rada u ovom broju časopisa pružiti uvid u funkcioniranje Sustava na regionalnoj razini, na primjeru lokalno specifične lutkarske predstave Park Cheomji Nori koju izvodi mala zajednica u ruralnom dijelu pokrajine Chungcheongnam. U njemu ću predstaviti rezultate terenskoga istraživanja provedenoga u rujnu 2017. godine u kojem sam sudjelovao kao dio istraživačkoga tima ${ }^{1}$ Korejskoga nacionalnog etnografskog muzeja. Moj zadatak bio je istražiti pogled baštinika na procese očuvanja ovoga fenomena nematerijalne kulturne baštine, s posebnim naglaskom na probleme očuvanja njegova wonhyeonga, ${ }^{2}$ tj. koncepta izvornoga oblika fenomena.

\section{OSNOVNE ZNAČAJKE SEOSANSKOGA PARK CHEOMJI NORI}

U pitoresknoj ruralnoj okolici Seosana, grada od oko 175.000 stanovnika u provinciji Chungcheongnam, nalazi se selo Tapgok (Sl. 1). Na prvi pogled ni po čemu se ne razlikuje od drugih na ovom području; broji oko 150 žitelja u ukupno 54 domaćinstva, a primaran izvor egzistencije radno sposobnih članova zajednice je poljoprivreda, točnije, uzgoj riže. Međutim, Tapgok je vrlo važan lokalitet na karti regionalne nematerijalne kulturne baštine jer se njegovi stanovnici aktivno bave očuvanjem vrlo specifične tradicijske lutkarske predstave koja se naziva Park Cheomji Nori.

U predindustrijskom kontekstu seosanski Park Cheomji Nori obično se izvodio u vremenu Chuseoka, žetvene svečanosti koja se priređuje petnaestoga dana osmoga lunarnog mjeseca u godini u kojem se obilježava dovršetak većine poljoprivrednih aktivnosti u Koreji (Cheon et al. [ur.] 2010: 212, 222). Kako se izvođenje predstave ne bi dovelo u pitanje, smatralo se uobičajenim da bogatije obitelji sponzoriraju izvođače predstave Park Cheomji Nori u novcu i naravi.

Park Cheomji Nori, karakterističan za područje ruralne okolice grada Seosana, nastao je pod utjecajem lutkarske predstave koja se naziva kkokdugaksi noreum, a dio je tzv. namsandang nori, složenoga performansa kojega su u selima priređivale trupe profe-

1 Najsrdačnije zahvaljujem kolegama iz Korejskoga nacionalnog etnografskog muzeja, abecednim redoslijedom to su: Cheon Jingji, Cho Haein, Choi Eunsoo, Jang Jang-sik, Kim Hyeongju, Kim Jongmin, Koo Mun Hoe, Lee Hyuna, Lee Kwan-Ho, Lee Nan-Young, Lee Yunha, Oh Changhyun, Oh Joonsuk, Park Hyeroung, Park Seonju, Sin Jeong Soo, Woo Seung Ha, Yi Kiwon; te članovima Društva za očuvanje seosanske predstave Park Chomji Nori: Kim Donk-iku, Yi Tae-suu. Posebno bih zahvalio Tomášu Pfejferu (Muzej lutaka u Plzenu) na nesebičnom dijeljenju terenskih bilješki i savjeta, kao i Sari Lustig (Kazalište Virovitica) i Vanji Gvozdiću (Gradsko kazalište "Zorin dom" Karlovac) na pomoći oko stručne terminologije u području lutkarstva.

2 Termin wonhyeong moguće je prevesti kao arhetip, koji se u kontekstu očuvanja nematerijalne kulturne baštine konstruira kao specifičan pojavni oblik određenoga fenomena. Formalno gledano, determinirati wonhyeong određenoga fenomena je nužan korak kako bi se on uvrstio u nacionalni registar ili regionalne registre nematerijalne kulturne baštine u Republici Koreji. Drugim riječima, sustav inzistira na povijesnoj autentičnosti koja treba biti zadržana bez promjene i u njemu se reflektira klasičan konfucijevski pristup dubokoga poštovanja prema staromu (usp. Howard 2002: 56). Više o wonhyeong i sustavu očuvanja nematerijalne kulturne baštine u Republici Koreji u Yim 2003; 2004 i Dronjić 2017. 
sionalnih putujućih zabavljača zvanih namsadang (Sl. 2). Namsadang nori obuhvaća nekoliko norija, ${ }^{3}$ dijelova nastupa koji čine cjelinu čiji je sastavni dio lutkarska predstava zvana kkokdugaksi noreum ili delomi. Značaj namsandang nori u kontekstu suvremenoga doživljaja korejske tradicijske kulture je izniman, o čemu svjedoči činjenica kako se njegovo aktivno očuvanje potiče na nacionalnoj i međunarodnoj razini. ${ }^{4}$ Međutim, u slučaju Park Cheomji Nori predstava se tijekom 20. stoljeća transformirala u samostalnu lokalnu tradiciju i danas se smatra jedinom korejskom lutkarskom predstavom koju izvodi lokalno stanovništvo (drugim riječima amateri), a ne profesionalni izvođači (Cheon et al. [ur.] 2010: 222-223; Heo 2003., 2011.).

Scena se sastoji od dvije grupe izvođača koje razdvaja pregrada u formi zastora obješena o konop rastegnut između dva stupa ili stabla. Lutkari zvani dejabi smješteni su iza zastora, skriveni od pogleda publike, dok se u prvom planu nalazi grupa glazbenika na aerofonim, idiofonim i membranofonim tradicijskim instrumentima. Tijekom predstave jedan od glazbenika aktivno komunicira s lutkama što je moguće protumačiti kao jedan od elemenata koji predstavi daje dinamiku (usp. Heo 2011: 6).

Predstava nosi ime glavnoga protagonista, starca Park Cheomjija (Sl. 3), o čijim zgodama i nezgodama progovara kroz dvadeset scena. ${ }^{5}$ Žanrovski, Seosan Park Cheomji Nori je satira koja propituje odnose između muškaraca i žena, nižih i viših društvenih slojeva, vjerskoga i svjetovnoga (Cheon et al. [ur.] 2010: 222-223), čime se nedvosmisleno uklapa u koncept kkokdugaksi noreum iz kojega i proizlazi. Međutim, iako ima mnogih podudarnosti u imenima i karakteristikama glavnih likova, kao i konzistencija u kompoziciji scena, zamjetni su određeni odmaci od inačica koje bi izvodile profesionalne trupe, čime je stvoren sadržaj koji ocrtava sustav vrijednosti lokalne seoske zajednice. Primjerice, kritika privilegiranih razvidna u sukobu između likova različitih društvenih slojeva je vrlo rigidna i višestruko koherentna. Također, za namsandang nori karakteristična je kritika budizma, ponekad i vrlo gruba, i to na način da se licemjerje svećenstva otvoreno ismijava. Međutim, seosanski Park Cheomji Nori prikazuje budizam u pozitivnom svjetlu, poglavito kroz prizmu ispunjenja nečije želje ili potrebe, što se posebno očituje u sceni u kojoj slijepac progleda. Za pretpostaviti je kako je za to zaslužan višestoljetni utjecaj obližnjih budističkih centara Buseokse i Gaesimse (Heo 2003: 360-361).

Lutke od prirodnih materijala kojih ima u izobilju u okolici, poput kore bora ili raznih mladica drveća, izrađuju sami mještani. Jedan od najomiljenijih materijala koji se i danas koristi u svrhu transfera znanja i vještina su tikvice kultivirane na specifičan način. Biljke se sade ispod rešetkastih konstrukcija na koje će se tijekom rasta početi

3 Termin nori ima značenje igre, predstave ili nastupa. Namsadang nori sastoji se od pungmul nori (glazbeno-plesna točka), beona nori (akrobatska točka u kojoj izvođači uz glazbenu pratnju vrte tanjure pomoću štapova ili motki), salpan (točka s akrobatskim elementima u kojoj dominira šaljivi dijalog između lika klauna i jednoga od izvođača), eoreum (hodanje po užetu), teotboegi (tradicijski ples pod maskama) i kkokdugaksi noreum ili delomi (lutkarska predstava).

$4 \quad$ Namsandang nori uvršten je u nacionalni Registar nematerijalne kulturne baštine 1964. godine (pod rednim brojem 3), a od 2009. godine dio je UNESCO-ove Reprezentativne liste nematerijalne kulturne baštine čovječanstva (Heo 2011: 6; UNESCO 2009.)

5 Snimak predstave moguće je pogledati na internetskim stranicama Korejskoga nacionalnog etnografskog muzeja (Enciklopedije korejske kulture): http://folkency.nfm.go.kr/kr/dic/2/video/1465 (pristup 19. travnja 2020.). 
penjati, nakon čega se odabiru plodovi koji slobodno vise. Na taj način se plodovi ne deformiraju, već se razvijaju u prepoznatljivu izduženu formu sa zadebljanjem na kraju koje će biti oblikovano u glavu lutke. Na nju se crtaju pojednostavljene crte lica, dok se brada i brkovi nerijetko apliciraju (u pojedinim slučajevima, također su nacrtane). Lutke su odjevene u odijela načinjena od obične tkanine, a nekima su pridodani rekviziti poput papirnatih pokrivala za glavu ili zastava. Međutim, neki likovi su složenije načinjeni, poput suca iz Pyongyanga koji jaše na konju. Na prvi pogled moguće je vrlo oprezno pretpostaviti kako je uzrok tomu vizualno naglašavanje njihova društvenoga statusa, međutim komparativnoga materijala za argumentaciju te tvrdnje je relativno malo. Naime, u prošlosti bi se većina lutaka zapalila nakon Chuseoka u skladu sa široko rasprostranjenim vjerovanjem kako maska u obiteljskom domu priziva zlonamjerne duhove. ${ }^{6}$ Pojedini istraživači su primijetili kako su "suvremene lutke znatno detaljnije i vizualno razrađenije od onih koje su se koristile u prošlosti" (Heo 2003: 362).

Prema tipu, koriste se ručne lutke ili lutke na štapu, glavni likovi nemaju nogu te ih publika vidi isključivo od struka nagore. Također, ako se promatra cjelokupna postava likova koji se javljaju u predstavi, razlika u veličini lutaka je itekako vidljiva. Glavni likovi su veći od sporednih, očigledan je disbalans u odnosu proporcija likova i arhitektonskih elementa koji su dio scenografije (zanimljivo je napomenuti kako ih izvođači ne smatraju scenografijom, već i likovima jer i njima "upravljaju” izvođači), dok su i neki fizički atributi samih likova prenaglašeni u odnosu na njihova tijela, što je najizrazitije u slučaju spolovila lika Hong Dongjija. Važno je naglasiti kako se navedene karakteristike ni u kojem slučaju ne trebaju smatrati lokalnim specifičnostima, već poveznicom s kkokdugaksi noreum koji izvode profesionalni izvođači u sklopu namsandang nori, u kojem se javljaju slični elementi. Razlog svjesnoga zanemarivanja proporcionalnih odnosa moguće je promatrati kao simbolički marker u kojem su sadržana kodirana značenja: "Umjesto reprodukcije objekta proporcionalno njegovoj stvarnoj veličini, smislenim se smatra ono što je prenaglašeno i veliko, čak i do razmjera koji se mogu smatrati pretjerivanjem." (Heo 2003: 361)

S tehničkoga gledišta, upravljanje lutkom je krajnje jednostavno. Izvođač u većini slučajeva upravlja likom pomoću ruke (u slučaju tipa ručne lutke) ili pomoću štapa, odnosno izduženoga tijela tikvice koji je skriven ispod odjeće (u slučaju tipa lutke na štapu). Lutke u pravilu nemaju pokretnih dijelova, izuzev Hong Dongjieva spolovila (univerzalna osobina lika) i lokalne inovacije koja se očituje u izvedbi lutke slijepca, odnosno u vizualnom efektu scene u kojoj mu se povrati vid, izvedenom tako da lutkar u pravodobnom trenutku neopaženo izvuče traku bijeloga papira koja joj pokriva oči (usp. Heo 2003: 369-370). Većini (glavnih) likova glasove posuđuju lutkari koji njima upravljaju, izuzev sporednih likova koji su "gotovo poput rekvizita u predstavi" (Heo 2003: 367). Tekst predstave je u lokalnom idiomu, tj. u dijalektu kojim govore stanovnici okolice Seosana.

6 Prema riječima kazivača Kim Dong-ika, današnjega voditelja lutkarske trupe, praksa paljenja lutaka napuštena je nakon što su počeli nastupati na lutkarskim festivalima diljem provincije tijekom devedesetih godina 20 . stoljeća jer su shvatili kako ih ljudi prepoznaju po lutkama. 
Jedna od lokalnih značajki je velik broj izvođača u odnosu na kkokdugaksi noreum (u kontekstu namsandang nori koji izvode profesionalne trupe), kod kojega jedna ili dvije osobe upravljaju svim lutkama te im posuđuju glasove. Seosanski Park Cheomji Nori izvodi šest do sedam lutkara (Sl. 4) te do desetak članova orkestra. Međutim, u prošlosti nije sudjelovalo toliko izvođača, već se broj postupno povećavao zahvaljujući interesu članova lokalne zajednice koji su željeli sudjelovati. Štoviše, jedna od glavnih značajki ovoga fenomena nematerijalne kulturne baštine je društvena konvencija koja nalaže da bilo tko može nastupiti ako zadovolji određene preduvjete. Primarno, mora znati tekst i naučiti upravljati lutkom, dok je jedan od preduvjeta u suvremenom kontekstu također postojanje slobodnoga mjesta u trupi (usp. Heo 2003: 364). Sudjelovanje žena postalo je široko rasprostranjena pojava tijekom kasnih osamdesetih godina 20. stoljeća, a zajednica je postupno razvila stav kako je bolje da žene daju glasove ženskim likovima koji je prisutan i danas. Zanimljivo, i liku svećenika žena daje glas, što se može smatrati još jednom specifičnom karakteristikom seosanskoga Park Cheomji Nori.

\section{OČUVANJE SEOSANSKOGA PARK CHEOMJI NORI KAO NEMATERIJALNE KULTURNE BAŠTINE}

Okolnosti nastanka i razvoja seosanskoga Park Cheomji Nori i dalje nisu u potpunosti razjašnjene. Prva istraživanja, započeta osamdesetih godina 20. stoljeća, rezultirala su studijom temeljenom na društvenom sjećanju i intervjuima s Ju Yeonsanom, tadašnjim vođom trupe, za kojega jedan od istraživača bilježi kako je "u poodmakloj dobi od 86 godina te ga pamćenje više ne služi kao prije" (Seo 2017: 9).

Ju Yeonsan tvrdio je kako ga je vještinama podučio stanoviti izvođač namsadangpae Yoo Young Choona tijekom dvadesetih godina 20. stoljeća u obližnjem okrugu Unsanmyeong. Ju je proveo tri godine u selu Shinchang-ri, gdje je usavršavao vještinu izrade lutaka i izvođenja predstave na seoskim svečanostima. Nakon povratka u Tapgok tijekom tridesetih godina 20. stoljeća, počeo je nastupati za vrijeme blagdana uz pomoć seoske mladeži (Seo 2017: 9-11). Smatra se kako je današnja inačica predstave više-manje oblikovana u periodu japanske okupacije (od 1910. do 1954. godine), ali zbog nedostatka pisanih izvora iz toga vremena gotovo je nemoguće pobliže utvrditi kada je započelo njezino izvođenje (usp. Foley 2016: 188). Već od sredine tridesetih godina 20. stoljeća, pa sve do kraja Korejskoga rata (od 1950. do 1953. godine) predstava se ne izvodi radi teških uvjeta u kojima se našla lokalna zajednica. Trupa se ponovno okupila nakon rata i započela redovito nastupati na seoskim svečanostima, čime su ujedno stvoreni temelji za provođenje procesa transfera umijeća na mlađe generacije. Ju Yeonsan umire 1990. godine, a ulogu voditelja trupe preuzima njegov učenik Kim Dong-ik, koji tu dužnost vrši do današnjih dana, aktivno tumačeći ulogu Park Cheomjija-a (Heo 2003: 379; Seo 2017: 9-11).

Osamdesete godine 20. stoljeća značajne su za seosanski Park Cheomji Nori i zato što je predstava emitirana diljem Koreje putem televizije, nakon čega se počinje redovito izvoditi u razdoblju Chuseoka i postupno postaje važan marker identiteta lokalne zajednice: "Drugim riječima, sociokulturni značaj predstave se pomiče sa 'zabave za 
suseljane' prema 'ponosu ili reprezentaciji sela"' (Heo 2003: 380). Nadalje, promjene u društvenom kontekstu postaju još izraženije nakon što 11. siječnja 2000. godine biva uvrštena u Registar nematerijalne kulturne baštine provincije Chungcheongnam pod rednim brojem 26 (Heo 2003: 380; Cheon et al. [ur.] 2010: 222).

Zahvaljujući angažmanu seosanskih gradskih vlasti u vidu financijske i administrativne pomoći, godine 2016. na periferiji Tapgoka otvoren je Centar čija je temeljna zadaća očuvanje seosanskoga Park Cheomji Nori. Godinu dana poslije, Centar je ugostio prvi festival lutkarskoga kazališta koji je popraćen stručnim skupom o očuvanju ovoga specifičnog fenomena nematerijalne kulturne baštine. Imao sam prilike osobno sudjelovati na ovoj manifestaciji te sam proveo nekoliko intervjua o izazovima očuvanja s voditeljima Društva za očuvanje seosanskoga Park Cheomji Nori, voditeljem trupe Kim Dong-ikom (osobom koja je sukladno zakonskoj regulaciji registrirana kao nositelj) (Sl. 5) i njegovim budućim nasljednikom, Yi Tae-suom (Sl. 6).

Prema njihovim riječima, trupa trenutno broji ukupno šesnaest uvjetno rečeno stalnih članova predvođenih majstorom Kim Dong-ikom. Na formalnoj razini, proces transfera znanja na mlađe generacije obuhvaća četvero učitelja i troje učenika, ali broj sudionika nije striktno ograničen jer se podrazumijeva kako im se bilo koji član zajednice može pridružiti u bilo kojem trenutku. Pojam stalnoga člana odnosi se na one osobe koje aktivno nastupaju, a radi se o stanovnicima sela starosti između 40 i 70 godina. Mlađi lutkari uskaču na njihovo mjesto ako se netko odseli, razboli se, odustane radi poodmakle dobi ili premine.

Iako članovi trupe nisu profesionalci, razradili su neformalni sustav namijenjen financijskoj konsolidaciji kako bi održali koheziju i doskočili eventualnim razmiricama u vezi s novcem. Naime, otkada je seosanski Park Cheomji Nori uvršten na regionalni popis nematerijalne kulturne baštine, osobama koje su prepoznate kao nositelji i instruktori koji sudjeluju u procesu transfera umijeća vlasti doznačuju zakonom propisanu financijsku potporu. Međutim, kako tom mjerom nisu obuhvaćeni svi članovi trupe, interno su se dogovorili kako će svaka osoba koja ima pravo na financijsku potporu donirati pola iznosa u zajednički fond iz kojega će se novac ravnomjerno dijeliti ostalima. Yi Taesu je naglasio kako je solidarnost zajednice od presudne važnosti za očuvanje ovoga fenomena baštine, što ne predstavlja naročiti izazov s obzirom na njezinu homogenost i relativno mali broj članova.

Kim Dong-ik je pojasnio da je njegov zadatak u svojstvu nositelja odabrati potencijalno najbolje nasljednike i osigurati im sve uvjete za usavršavanje umijeća izrade lutaka i igranja predstave. Tijekom toga procesa moraju slijediti njegova pravila i upute te godinama vježbati prije nego dobiju priliku javno nastupati. Također, naglasio je kako proces treba shvatiti ozbiljno, ali isto tako ne treba iz vida izgubiti kako se potrebno zabavljati i uživati u izvođenju predstave jer je ona u konačnici nori (igra) u punom smislu riječi. Istaknuo je i kako su prema njegovim saznanjima neki mlađi sumještani ostali u selu upravo radi mogućnosti učenja i mogućega nastupanja u predstavi, zaključivši kako smatra da je ovaj fenomen nematerijalne kulturne baštine od iznimne važnosti za opstojnost zajednice. Konačno, izrazio je želju da seosanski Park Cheomji 
Nori jednoga dana bude uvršten i u nacionalni Registar nematerijalne kulturne baštine, kao i ambiciju da se to dogodi još za njegova života.

Danas trupa izvodi oko petnaestak predstava godišnje, a Yi Tae-su smatra kako bi trebali nastupati i više. Primarni razlozi su stjecanje iskustva, pružanje prilike mlađim članovima i promocija vlastitoga sela. Predstave se održavaju diljem područja koje administrativno pripada Seosan Cityju, a želja većine je da se prošire na prostore susjednih gradova i općina. Unatoč tomu, članovi trupe naglasili su kako su im suseljani najbolji kritičari, ističući kako ih uvijek upozore ako je odigrana predstava bila ispod očekivane razine kvalitete. Također, Yi Tae-su naglasio je kako je posljednjih desetak godina napravljen veliki napredak u suradnji s lokalnim osnovnim i srednjim školama, za čije polaznike primarno izvode predstave, radionice izrade lutaka te ostale edukativne programe kojima je cilj očuvanje i promocija lokalne baštine.

Većina mještana naglasila je kako zbog brojnih vidljivih postignuća Yi Tae-sua vide kao budućega voditelja trupe i Društva za očuvanje seosanskoga Park Cheomji Norija, poglavito zbog uspješnoga okončanja projekta uspostave Centra koji je postao simbol napretka cijele zajednice te pokretač i središte mnogobrojnih komunalnih aktivnosti, od neformalnih sastanaka do javnih manifestacija. Sastoji se od ljetne pozornice, velike dvorane za probe i nastupe, dok je u foajeu i izložbeni prostor u kojem se pretežno izložene lutke koje se više ne koriste i fotografije trupe kroz povijest. Iako je ideja njegove izgradnje stara nekoliko desetljeća, mnogi su suseljani bili skeptični kada su započeli radovi, naročito nakon što su im predstavljeni financijski detalji. Međutim, zajednica se uspješno konsolidirala zahvaljujući entuzijazmu Yi Tae-sua, a zahvaljujući pozitivnim promjenama u politikama seosanskih gradskih vlasti koje su detektirale želju za promocijom Seosan Cityja kroz prizmu kulture i baštine, Centar je otvorio svoja vrata. Gledano s odmakom od godine dana, lokalna zajednica načelno podupire ideju seosanskih gradske vlasti, ali njezini predstavnici naglašavaju kako su dodatna financijska ulaganja, kao i ulaganja u operativne kapacitete, nužna. Primjerice, jedan od ključnih izazova za lokalnu zajednicu je kako efikasno i uspješno upravljati Centrom, uzevši u obzir da zapošljava samo jednu osobu koja je zadužena za izvršavanje zadataka administrativne prirode. U prilog tomu ide i činjenica kako seosanske gradske vlasti na ovom području žele razviti klaster lokacija baštinskoga predznaka kako bi zahvaljujući posjetiteljima osigurali načelo samoodrživosti razvojnih projekata. Međutim, stanovnici Tapgoka još uvijek nisu u mogućnosti samostalno adresirati ove izazove. Spremno naglašavaju kako nemaju ništa protiv prezentiranja svoje baštine turistima, ali i da su svjesni kako bi takva budućnost sa sobom mogla donijeti i neke neizbježne promjene.

Većina izazova vezanih uz procese očuvanja seosanskoga Park Cheomji Norija proizlazi iz relativne inkompatibilnosti "staroga" sustava vrijednosti sa suvremenim načinom života u Republici Koreji. Prvenstveno se propituje odnos učitelja i učenika koji uspostavlja proces transfera umijeća i znanja, a koji je baziran na striktnoj konfucijanističkoj paradigmi odnosa. Primjerice, Kim Dong-ik kao izazov naglašava da njegovi učenici silno žele nastupati iako on smatra kako još uvijek nisu spremni, što interpretira kao ignoriranje autoriteta. S druge strane, Yi Tae-su ističe kako je za uspješno očuvanje ovoga fenomena nematerijalne kulturne baštine potrebno razviti malo drugačiji pristup, 
onaj koji će nužno omogućiti svim zainteresiranima da sudjeluju i koji će ih dodatno ohrabrivati tijekom procesa.

Sam čin nastojanja da se seosanski Park Cheomji Nori očuva kao nematerijalna kulturna baština pokrajine Chungcheongnam pokrenuo je niz promjena u njegovu kontekstu. Uz prije spomenuto povećanje broja nastupa, u prvom redu izvan razdoblja godine u kojem je Chuseok, promijenio se i prostorni kontekst same predstave. Jednostavna scena na otvorenom, konstruirana pomoću platna prebačena preko konopa rastegnuta između dva stabla zamijenjena je dvoranom opremljenom poput bilo kojega suvremenog kazališta. Drugim riječima, predstava je doslovce stala pod svjetla pozornice što je otvorilo određene izazove, primarno u kontekstu održavanja izvornoga oblika fenomena, tzv. wonhyeonga, koji i dalje predstavlja kamen spoticanja u implementaciji mjera očuvanja, a posebno je vidljiv kod prije istaknutih razmišljanja različitih generacija baštinika.

S prestižem koji se pojavio kao rezultat uspješnoga uvrštenja ovoga fenomena nematerijalne kulturne baštine u regionalan registar, seosanski Park Cheomji Nori prestaje se smatrati pukom seoskom zabavom i poprima određene umjetničke nadgradnje. Primjerice, to je posebno vidljivo kod izrade lutaka koje postaju sve dotjeranije, što se javlja kao posljedica želje izrađivača da iskažu razinu vlastite vještine (usp. Heo 2003: 383-384, Aikawa-Faure 2014: 46). Tijekom dvadesetoga stoljeća nije postojala takva praksa jer su lutke bile gotovo jednokratne, odnosno služile su isključivo za izvođenje predstave u vremenu Chuseoka, nakon čega bi bile uništene u skladu s lokalnim vjerovanjima. Danas potreba za lutkama nije ograničena na svečanost, već su nužan rekvizit za izvođenje predstave ili postaju materijalna baština koja se izlaže u foajeu Centra.

Promjene u predstavi koje se događaju kao posljedica promjene konteksta vidljive su i u modifikacijama teksta. Iako su i Kim Dong-ik i Yi Tae-su naveli kako inzistiraju na originalnom sadržaju u duhu održavanja wonhyeonga, napomenuli su kako je ipak bilo određenih promjena u prošlosti koje su ubrzo napuštene jer su naišle na neodobravanje kod lokalne publike. Suprotno tomu, pojedine inovacije su prihvaćene s velikim entuzijazmom, poput mehanizma ugrađenoga u lutku slijepca ili sudjelovanja žena, što otvara prostor za propitivanje svrsishodnosti koncepta wonhyeonga u smislu "baštinske" norme na kojoj zakonodavac insistira. Konačno, pojedine alternacije teksta bile su neizbježne jer se broj govornika seosanskoga dijalekta (koji je važan element njegova izvornoga oblika) rapidno smanjuje, kako među publikom, tako i među samim izvođačima.

Neke od intervencija u izvornu formu teksta potrebno je sagledati i u svjetlu umjetničke produkcije inspirirane fenomenom nematerijalne kulturne baštine. Prije nekoliko godina, jedno kazalište iz Seosana izvelo je Novi seosanski Park Cheomji Nori, kraću i znatno dinamičniju adaptaciju predstave. Kim Dong-ik utvrdio je kako je ta "intervencija" itekako problematična jer je prema njegovu mišljenju, među ostalim, publika ujedno lišena i doživljaja originalnoga konteksta. Međutim, u pomirljivom je tonu zaključio kako "oni to rade iz zabave i za zabavu pa je i to nori", u čemu je vidljiva gradacija elemenata sustava vrijednosti baštinika koji uzimaju u obzir koncept wonhyeonga, ali ga ne pretpostavljaju socijalnom kontekstu. 


\section{ZAKLJUČAK}

Seosanski Park Cheomji Nori razvio se iz tradicije kkokdugaksi noreum u prvoj polovici 20. stoljeća u jedinu lokalno specifičnu lutkarsku predstavu koju izvodi amaterska trupa sastavljena od stanovnika sela Tapgok. Do osamdesetih godina bio je nepoznat široj javnosti, a nakon sustavnih istraživanja biva uvršten u Registar nematerijalne kulturne baštine pokrajine Chungcheongnam 2000. godine, čime je formalno započet proces očuvanja seosanskoga Park Cheomji Nori. Petnaestak godina poslije, gradske vlasti Seosan Cityja investiraju u izgradnju Centra koji uz prostor za uvježbavanje, izvedbe, radionice i događanja preuzima ulogu središnjega okupljališta zajednice, u nadi da će potaknuti razvoj sela uključivši ga na turističku kartu baštinskih lokaliteta ovoga područja. Međutim, iako se funkcioniranje centra u kontekstu samoodrživosti istaknulo kao novi izazov postavljen pred zajednicu, neosporna je činjenica da je konsolidirao njezine članove oko seosanskoga Park Cheomji Nori te ga postupno promiče u jedan od najvažnijih markera lokalnoga identiteta.

Možda je upravo ključan kriterij po kojem je moguće suditi je li seosanski Park Cheomji Nori primjer stabilnoga procesa očuvanja nematerijalne kulturne baštine Republike Koreje na regionalnoj razini upravo subjektivna procjena lokalne zajednice. Mještani smatraju kako je s otvaranjem Centra ostvaren napredak koji se očekivao otkako su fenomen uvršten $\mathrm{u}$ regionalni registar, a posebno ih veseli što se Yi Tae-su promiče u nasljednika Kim Dong-ika. Drugim riječima, iz njihove perspektive Sustav je ispunio svoju zadaću - seosanski Park Cheomji Nori ima budućnost. Mišljenja sam kako je entuzijazam i solidarnost zajednice uvelike izgrađeni oko modela inkluzije njezinih članova u širem smislu od samoga sudjelovanja u predstavi. Kao što su članovi trupe naglasili, zajednica je najbolji kritičar, a projekt seosanskoga Park Cheomji Nori je komunalni projekt.

S druge strane, jedan od najozbiljnijih izazova je kako pomiriti sustavni imperativ očuvanja izvornoga oblika fenomena uslijed promjena konteksta (wonhyeong). Unatoč činjenici kako je zajednica u prošlosti podržala određene intervencije (primjerice, sudjelovanje žena), sam čin ulaska u sustav očuvanja nematerijalne kulturne baštine na regionalnoj razini, kao i otvorene ambicije izvođača da se očuvanje seosanskoga Park Cheomji Nori podigne na nacionalnu razinu, implementira određene mjere koje dovode u pitanje glas odluke te iste zajednice.

Ključno je pitanje može li se izvorni oblik uopće normirati, pogotovo kad se uzmu u obzir nužne intervencije koje se implementiraju nakon uvrštenja seosanskoag Park Cheomji Nori u regionalni registar? Drugim riječima, je li sam Sustav očuvanja potencijalna prijetnja procesu očuvanja? Ili kako Yang upozorava: “...promjena društvenih okolnosti koja se manifestira na određenom fenomenu nematerijalne kulturne baštine trebala bi biti evidentna u njezinom suvremenom obliku, jer će interes javnosti za njezin 'petrificirani' oblik nestati jer današnja publika nema isti ukus kao ona iz prošlosti.” (Yang 2003: 12)

Iako se ovo pitanje postavlja u kontekstu rasprave o korejskom sustavu, ono je zapravo globalno. Također, iluzorno je smatrati kako je na njega moguće dati univerzalan odgovor. Međutim, tijekom istraživanja u Republici Koreji, svjedočio sam jednom specifičnom 
primjeru indirektne promocije nematerijalne kulturne baštine mlađoj publici koji na određeni način adresira Yangovo upozorenje. U Nacionalnom Gugak Centru ${ }^{7}$ u Seulu imao sam priliku pogledati lutkarsku predstavu "Park Cheomji se vraća" u produkciji Sanineomeo Theater Company, koja spaja tradicijski predložak sa suvremenim glazbenim i plesnim izričajem. Primjerice, u jednoj sceni se pojavljuje lutka odjevena u košarkaški dres koja izvodi hip-hop dionicu, dok u drugoj likovi djevojaka (pijori) počinju pjevati potaknuti ritmom planetarno popularne pjesme Gangnam Style korejskoga izvođača PSY-a. Predstava je bila namijenjena djeci predškolskoga ili osnovnoškolskoga uzrasta (nosila je oznaku 3+) te je bilo evidentno kako mališani gube koncentraciju za vrijeme dijaloških ili plesnih dionica koje se baziraju na tradicijskom predlošku, fokusirajući svoju pažnju na igračke koje su ponijeli ili roditeljske telefone. Međutim, bljeskovi poznatoga sadržaja vraćali su ih u predstavu. Iz primjera je razvidno kako se izvorni oblik nužno mora oslanjati na suvremene interpretativne alate kako bi postao interesantan publici kojoj je namijenjen, ali u kontekstu očuvanja nematerijalne kulturne baštine važno je naglasiti kako je novim generacijama potrebno prenijeti širu sliku ili - kako je to Kim Dong-ik mnogo puta naglasio - nori treba biti nori.

\section{LITERATURA I IZVORI:}

AIKAWA-FAURE, Noriko. 2014. "Excellence and authenticity: 'Living National (Human) Treasures' in Japan and Korea”. International Journal of Intangible Heritage 9: 38-51.

CHEON, Jingji, CHOI, Soon-geun, AN, Jeong-yun, OH, Chang hyun, KIM, Hyun-Kyung, LEE, Chang kyu, YOO, Juyi i Jo-heun YI. (ur.) 2010. Encyclopedia of Korean Folklore and Traditional Culture Vol. 1: Encyclopedia of Korean Seasonal Customs. Seul: National Folk Musum of Korea.

DRONJIĆ, Matija. 2017. "Kratak pregled sustava zaštite nematerijalne kulturne baštine u Republici Koreji”. Etnološka istraživanja 22: 9-25.

FOLEY, Kathy. 2016. "Puppets in traditional Asian theatre". U: Handbook of Asian Theatre. New York: Routledge, str. 177-201.

HEO, Yong-ho. 2003. “서산박첨지놀이의 전승 양상”. Korean Journal of Folk Studies 13: 353-392.

HEO, Yong-ho. 2011. "Puppetry Traditions in Korea and Kkokdu Gaksi Noreum". ICH Courier 7: 6.

HOWARD, Keith. 2002. "Living human treasures from the lost age: Current issues in cultural heritage management”. Korean Research Journal of Dance Documentation 3: 52-74.

KILLICK, Andrew. 2016. "Korea”. U: Handbook of Asian Theatre. New York: Routledge, str. 146-149.

7 Središnja institucija za očuvanje i promociju korejskoga tradicionalnog glazbenog izričaja (gugak). 
KIM, Chang Gyoo, CHOE, Jong Ho, JEONG, Yu Gyeong i Gi-young JEONG. 2012. A Safeguarding System for Cultural Heritage in Korea: Focused on the Activities of Restoration, Transmission and Protection of Designated Cultural Properties. Daejon - Buyeo: Cultural Heritage Administration - Korean National University of Cultural Heritage.

SEO, Yeon-ho. 2017. “서산박첨지놀이의 발견 과정과 옛 모습”. U: 서산박첨지놀이의 학술대회 Seosan: Park Cheomji Nori Preservation Society, str. 9-20.

UNESCO [United Nations Educational, Scientific and Cultural Organization]. 2009. Representative List of the Intangible Cultural Heritage. Paris: UNESCO.

YANG, Jongsung. 2003. Cultural Protection Policy in Korea: Intangible Cultural Properties and Living National Treasures. Seoul - Edison: Jimoondang - Jimoondang International.

YANG, Jongsung. 2004. "Korean Cultural Property Protection Law with Regard to Korean Intangible Heritage”. Museum International 56 (1-2): 180-188. https://doi.org/10.1111/ j.1350-0775.2004.00473.x

YIM, Dawnhee. 2004. "Living Human Treasures and the Protection of Intangible Culture Heritage: Experiences and Challenges". ICOM News 4/2004: 10-12. 